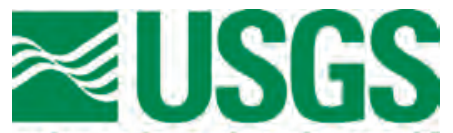

science for a changing world

Prepared in cooperation with the Osage Tribal Council

\title{
Aquifer Tests and Characterization of Transmissivity, Ada- Vamoosa Aquifer on the Osage Reservation, Osage County, Oklahoma, 2006
}

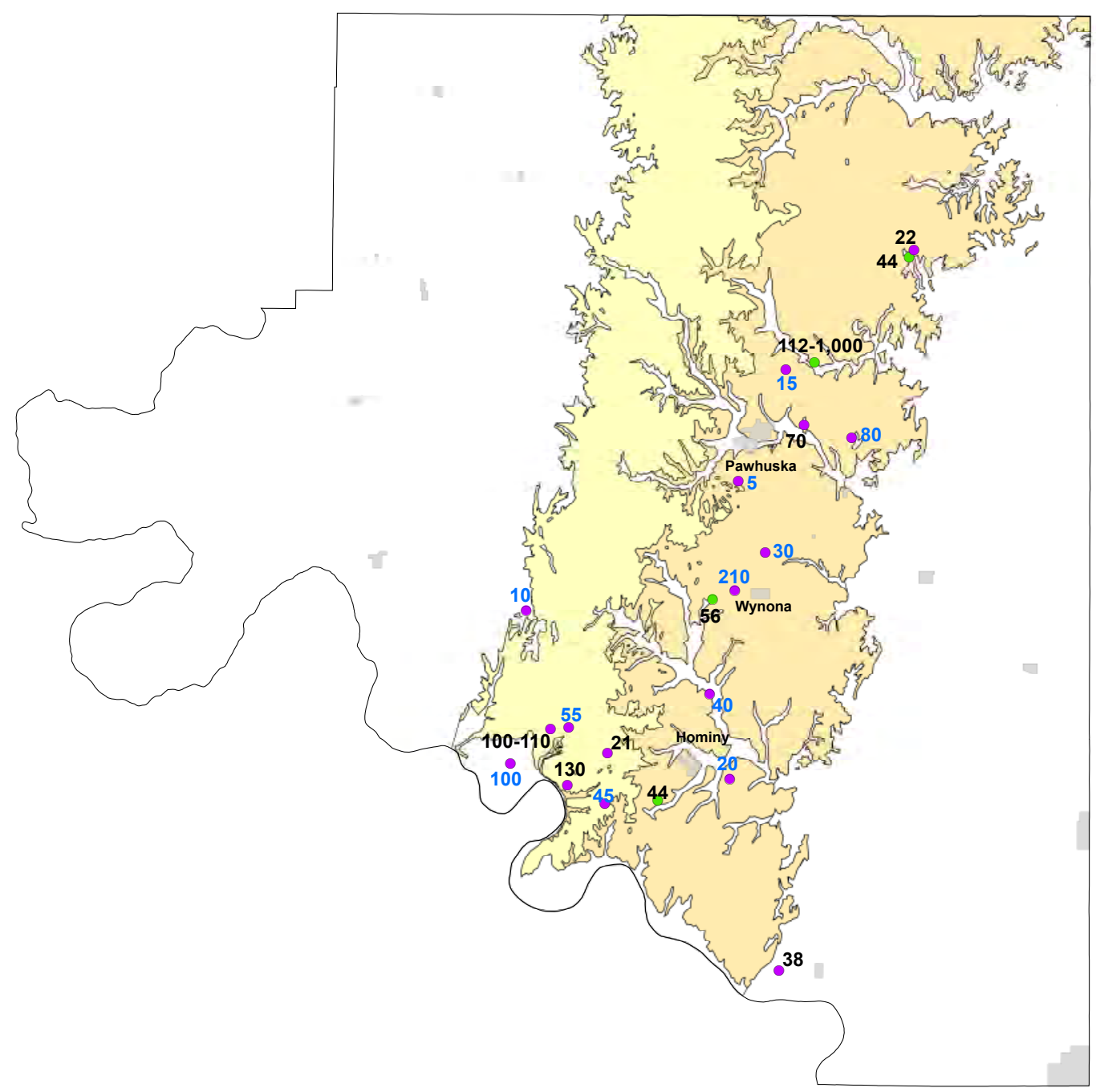

Scientific Investigations Report 2008-5118 
On the cover: Map of Osage Reservation, Osage County, with the Ada-Vamoosa a quifer outlined. 


\section{Aquifer Tests and Characterization of Transmissivity, Ada-Vamoosa Aquifer on the Osage Reservation, Osage County, Oklahoma 2006}

By Marvin M. Abbott and Kelli DeHay

Prepared in cooperation with the Osage Tribal Council

Scientific Investigations Report 2008-5118 


\section{U.S. Department of the Interior DIRK KEMPTHORNE, Secretary}

\section{U.S. Geological Survey \\ Mark D. Myers, Director}

\section{U.S. Geological Survey, Reston, Virginia: 2008}

For product and ordering information:

World Wide Web: http://www.usgs.gov/pubprod

Telephone: 1-888-ASK-USGS

For more information on the USGS--the Federal source for science about the Earth, its natural and living resources, natural hazards, and the environment:

World Wide Web: http://www.usgs.gov

Telephone: 1-888-ASK-USGS

Any use of trade, product, or firm names is for descriptive purposes only and does not imply endorsement by the U.S. Government.

Although this report is in the public domain, permission must be secured from the individual copyright owners to reproduce any copyrighted materials contained within this report.

Suggested citation:

Abbott, M.M., and DeHay, Kelli, 2008, Aquifer tests and characterization of transmissivity, Ada-Vamoosa Aquifer on the Osage Reservation, Osage County, Oklahoma, 2006: U.S. Geological Survey Scientific Investigations Report 2008-5118, $10 \mathrm{p}$. 


\section{Contents}

Abstract
Introduction.
Purpose and Scope
Gescription of the Aquifer in the Study Area
Aquifer Data and Field Methods
Aquifer Test Analysis Methods and Results
Characterization of Transmissivity
References.

\section{Figures}

Figures 1-4. Maps showing:

1. Distribution of the outcrop area of the Ada-Vamoosa aquifer and the specific

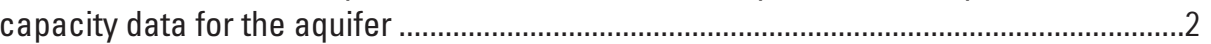

2. Distribution of the outcrop area of the Ada-Vamoosa aquifer and the calculated and estimated transmissivity data for the aquifer........................................................

3. Comparison of the calculated and estimated transmissivity data with the data from Oklahoma Geological Survey Circular 87 for the unconfined part of the Ada-Vamoosa aquifer

4. Comparison of the calculated and estimated transmissivity data with the data from Oklahoma Geological Survey Circular 87 for the confined part of the Ada-Vamoosa aquifer.

\section{Tables}

1. Ada-Vamoosa aquifer properties from wells in Creek, Payne, and Lincoln Counties ......3

2. Ada-Vamoosa aquifer test information, including pumping rate, water-level drawdown, specific capacity, estimated and calculated transmissivity, and calculation method used 


\section{Conversion Factors}

Inch/Pound to SI

\begin{tabular}{|c|c|c|}
\hline Multiply & By & To obtain \\
\hline \multicolumn{3}{|c|}{ Length } \\
\hline foot $(\mathrm{ft})$ & 0.3048 & meter $(\mathrm{m})$ \\
\hline \multicolumn{3}{|c|}{ Area } \\
\hline square mile $\left(\mathrm{mi}^{2}\right)$ & 2.590 & square kilometer $\left(\mathrm{km}^{2}\right)$ \\
\hline \multicolumn{3}{|c|}{ Flow rate } \\
\hline gallon per minute (gal/min) & 0.06309 & liter per second $(\mathrm{L} / \mathrm{s})$ \\
\hline \multicolumn{3}{|c|}{ Pressure } \\
\hline pound per square inch $\left(\mathrm{lb} / \mathrm{in}^{2}\right)$ & 6.895 & kilopascal $(\mathrm{kPa})$ \\
\hline \multicolumn{3}{|c|}{ Specific capacity } \\
\hline $\begin{array}{l}\text { gallon per minute per foot } \\
[(\mathrm{gal} / \mathrm{min}) / \mathrm{ft})]\end{array}$ & 0.2070 & liter per second per meter $[(\mathrm{L} / \mathrm{s}) / \mathrm{m}]$ \\
\hline \multicolumn{3}{|c|}{ Transmissivity* } \\
\hline foot squared per day $\left(\mathrm{ft}^{2} / \mathrm{d}\right)$ & 0.09290 & meter squared per day $\left(\mathrm{m}^{2} / \mathrm{d}\right)$ \\
\hline
\end{tabular}

Vertical coordinate information is referenced to the North American Vertical Datum of 1988 (NAVD 88).

Horizontal coordinate information is referenced to the North American Datum of 1983 (NAD 83).

*Transmissivity: The standard unit for transmissivity is cubic foot per day per square foot times foot of aquifer thickness $\left[\left(\mathrm{ft}^{3} / \mathrm{d}\right) / \mathrm{ft}^{2}\right] \mathrm{ft}$. In this report, the mathematically reduced form, foot squared per day $\left(\mathrm{ft}^{2} / \mathrm{d}\right)$, is used for convenience. 


\title{
Aquifer Tests and Characterization of Transmissivity, Ada- Vamoosa Aquifer on the Osage Reservation, Osage County, Oklahoma, 2006
}

\author{
By Marvin M. Abbott and Kelli DeHay
}

\begin{abstract}
The Ada-Vamoosa aquifer of northeastern Oklahoma is a sedimentary bedrock aquifer of Pennsylvanian age that crops out over 800 square miles of the Osage Reservation. The Osage Nation needed additional information regarding the production potential of the aquifer to aid them in future development planning. To address this need, the U.S. Geological Survey, in cooperation with the Osage Nation, conducted a study of aquifer properties in the Ada-Vamoosa aquifer. This report presents the results of the aquifer tests from 20 wells in the Ada-Vamoosa aquifer and one well in a minor aquifer east of the Ada-Vamoosa outcrop on the Osage Reservation. Well information for 17 of the 21 wells in this report was obtained from the Indian Health Service. Data collected by the U.S. Geological Survey during this investigation are pumping well data from four domestic wells collected during the summer of 2006. Transmissivity values were calculated from well pumping data or were estimated from specific capacity values depending on the reliability of the data. The estimated transmissivity values are 1.1 to 4.3 times greater than the calculated transmissivity values. The calculated and estimated transmissivity values range from 5 to 1,000 feet squared per day.
\end{abstract}

\section{Introduction}

The Ada-Vamoosa aquifer of northeastern Oklahoma is a sedimentary bedrock aquifer of Pennsylvanian age that crops out over 800 square miles of the Osage Reservation (Bingham and Bergman, 1980, sheets 1 and 2). The Osage Nation needed additional information regarding the production potential of the aquifer to aid them in future development planning. A previous ground-water-quality study of the aquifer (Abbott, 2000) provided water-quality data in rural domestic wells and compared water quality to proximity of oil wells. The Abbott (2000) study did not provide information regarding the potential water yield of the aquifer and this information can be used by the Osage Nation to evaluate the aquifer as a resource.
To address this need, the U.S. Geological Survey (USGS), in cooperation with the Osage Nation, conducted a study of aquifer properties on the reservation.

\section{Purpose and Scope}

The purpose of this report is to present the results of the aquifer tests and characterization of transmissivity from 20 wells in the Ada-Vamoosa aquifer and one well in a minor aquifer east of the Ada-Vamoosa outcrop on the Osage Reservation. Transmissivity values were calculated from well pumping data or were estimated from specific capacity values depending on the reliability of the data. The well transmissivity values are compared to selected published aquifer hydraulic data (D'Lugosz and others, 1986) to present a regional spatial interpretation.

\section{Description of the Aquifer in the Study Area}

The study area was about the extent of the outcrop area of the Ada and Vamoosa Formations on the reservation. The eastern boundary is the outcrop of the lower units of the Vamoosa Formation. The western boundary is the limit of usable water in the aquifer. This approximately corresponds to the western limits of the Ada Formation.

Descriptions of the aquifer were obtained from drilling information required by the U.S. Department of Health and Human Services, Indian Health Service (IHS) in Pawnee, Oklahoma, and other references as listed. IHS data includes date the well was tested, latitude, longitude, lithology thicknesses, well depth, screen interval, screen depth, pumping rate, and well-test drawdown information.

The Ada-Vamoosa aquifer is composed of sedimentary bedrock of Pennsylvanian age that crops out from near Sulphur in south-central Oklahoma to the Osage Reservation (fig. 1). The outcrop for the Ada-Vamoosa aquifer (fig. 1) system 


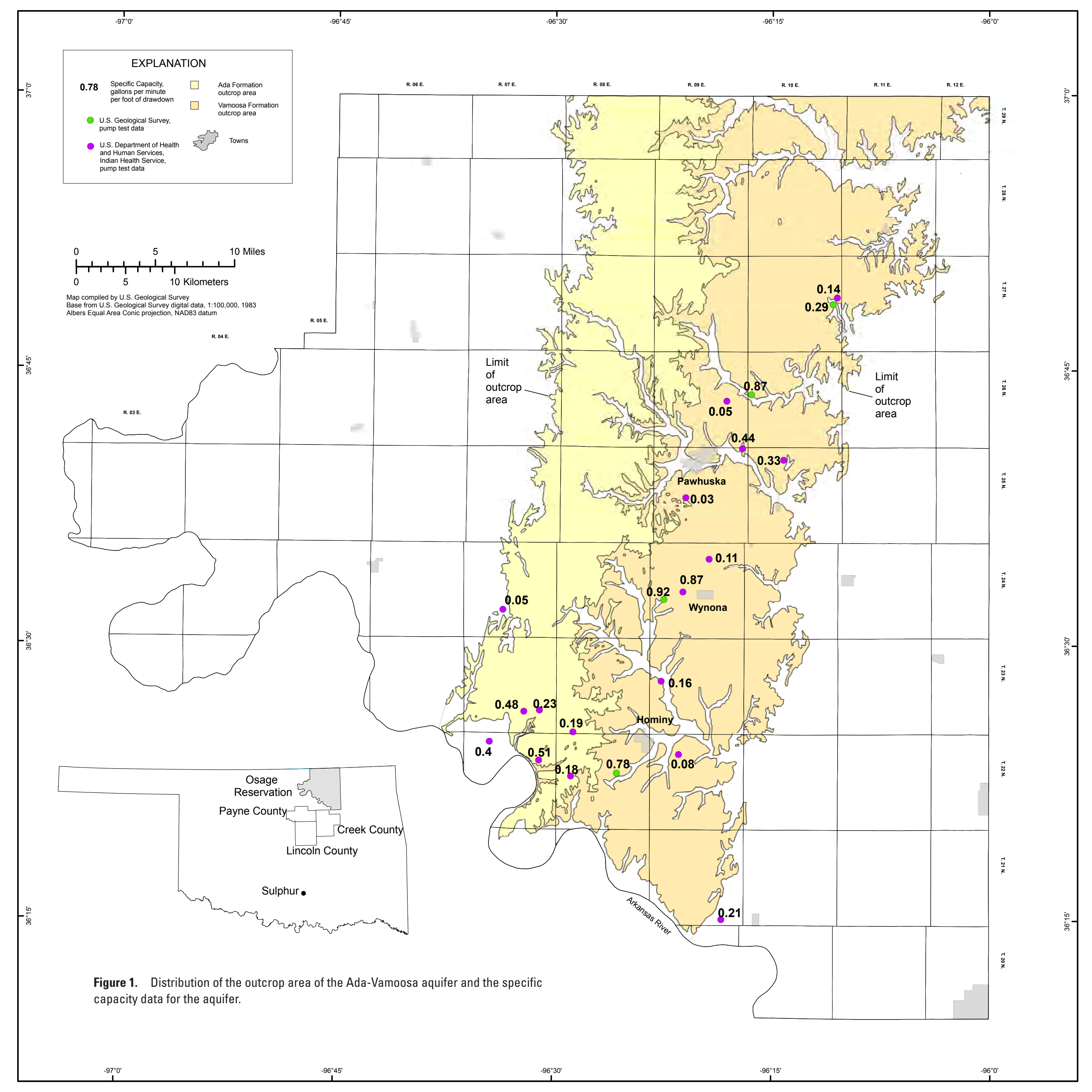


includes about 800 square miles of the Osage Reservation or about 35 percent of the surface area in a broad north-south band (Bingham and Bergman, 1980, plates 1 and 2).

The Ada Formation, the upper unit of the aquifer, is about 400 feet thick and consists of interbedded limestone and shale units near the Kansas border. The Ada Formation grades into fine-grained sandstones interbedded with limestone and shale near the southern border of the reservation (Bingham and Bergman, 1980, plate 1). The lower members of the Ada Formation are seen in limestone quarries west of Pawhuska. The Ada Formation probably supplies little of the water produced from the aquifer on the reservation.

The Vamoosa Formation, the lower unit of the aquifer, is about 630 feet thick and consists of alternating layers of shale and fine- to coarse-grained sandstone with some limestone (Bingham and Bergman, 1980, plate 1). Sandstone units vary from 5 to 60 feet in thickness. The sandstone aquifer is confined by the alternating shale beds in the Vamoosa Formation, except where the sandstone units crop out. The sandstones are cemented with clay and calcite (Oakes, 1959; Greig, 1959; and Shelton and others, 1985). The sources of sediment for the aquifer were the Arbuckle and Ouachita Uplifts in southern and southeastern Oklahoma (D'Lugosz and others, 1986).

The aquifer is thicker and sandstones comprise a greater percentage nearer the sediment sources to the south and southwest. The regional dip of the aquifer is generally less than 1 degree to the west (D'Lugosz and others, 1986). Movement of water in the aquifer is assumed to be down the regional dip.

\section{Ground-Water Hydrologic Terms}

The following terms of ground-water hydrology are defined in Lohman and others (1972), Heath (1983), and Driscoll (1986) along with a discussion of basic ground-water hydrology. An aquifer is a geologic formation, group of formations, or part of a formation that contains sufficient saturated permeable material to yield significant quantities of water to springs and wells. An unconfined aquifer occurs where the aquifer is exposed to the atmosphere locally through the openings in the overlying regolith. A confined aquifer is isolated from the atmosphere at the point of discharge by impermeable rocks such as shales and clays. Static water level is the level at which water stands in a well when no water is being removed from the aquifer. Pumping water level is the level at which water stands in a well when pumping is in progress. Drawdown is the difference between the water level in a well before pumping and the water level in the well during pumping. Hydraulic conductivity is the capacity of a rock to transmit water, and is expressed as the volume of water at the existing kinematic viscosity that will move in unit time under a unit hydraulic gradient through a unit area measured at right angles to the direction of flow. Transmissivity is the rate at which water of the prevailing kinematic viscosity is transmitted through a unit width of an aquifer under a unit hydraulic gradient, and equals the hydraulic conductivity multiplied by the aquifer thickness. Specific capacity is the yield of a well per unit of drawdown.

\section{Aquifer Data and Field Methods}

Aquifer data for the Ada-Vamoosa aquifer have been published in Oklahoma Geological Survey Circular 87 (D'Lugosz and others, 1986). Transmissivity values ranged from 117 to 325 feet squared per day (table 1) for four wells outside the study area in Creek, Lincoln, and Payne Counties (fig. 1) (D’Lugosz and others, 1986).

The data for Circular 87 was compiled as a regional perspective of the aquifer. Circular 87 utilized about 600 borehole geophysical logs from oil wells to interpret the aquifer in the subsurface. Borehole geophysical data are obtained during the drilling of oil wells after the surface casing is in place, after the well is drilled to a total depth, and before the well is completed. Estimates of the lithology, sandstone thickness, lateral distribution of lithologies, and electrical conductivity of the water can be obtained from the geophysical log data. The shallowest rocks, which are protected by the surface casing, are not part of the data. The lithology of the shallow zone was assumed to be the same as that on logs in nearby wells down dip to the west. Circular 87 divided the aquifer into uncon-

Table 1. Ada-Vamoosa aquifer properties from wells in Creek, Payne, and Lincoln Counties.

[gpm, gallons per minute; ft, foot; gpm/ft, gallons per minute per foot; $\mathrm{ft}^{2} / \mathrm{d}$, feet squared per day, data from D’Lugosz and others, 1986; estimated transmissivity values $=242 *$ pumping rate $\div$ drawdown $]$

\begin{tabular}{llcccc}
\hline \multicolumn{1}{c}{ Location } & County & $\begin{array}{c}\text { Pumping rate } \\
\mathbf{( g p m )}\end{array}$ & $\begin{array}{c}\text { Drawdown } \\
(\mathbf{f t})\end{array}$ & $\begin{array}{c}\text { Specific } \\
\text { capacity } \\
(\mathbf{g p m} / \mathbf{f t})\end{array}$ & $\begin{array}{c}\text { Estimated } \\
\text { transmissivity } \\
\left(\mathbf{f t} \mathbf{t}^{2} \mathbf{d}\right)\end{array}$ \\
\hline $17 \mathrm{~N}-07 \mathrm{E}-08 \mathrm{CBD}-1$ & Creek & 110 & 161 & 0.68 & 165 \\
$12 \mathrm{~N}-06 \mathrm{E}-27 \mathrm{BCB}-1$ & Lincoln & 90 & 186 & 0.48 & 117 \\
$15 \mathrm{~N}-06 \mathrm{E}-28 \mathrm{DBD}-1$ & Lincoln & 40 & 57 & 0.70 & 170 \\
$17 \mathrm{~N}-05 \mathrm{E}-03 \mathrm{ACB}-1$ & Payne & 208 & 155 & 1.34 & 325 \\
\hline
\end{tabular}


fined and confined units based on the borehole geophysical data.

In a shallow ground-water system with low dissolved solids concentrations, borehole geophysical logs do not distinguish thin sandstones from limestones. Throughout much of the regional extent of the aquifer south of the reservation, the Ada Formation is predominately a sandstone and shale sequence. On the Osage Reservation, the Ada Formation is a limestone and shale sequence except near the southern boundary along the Arkansas River. The lithology change was not noted in the discussion of the aquifer in Circular 87 and thus was probably not taken into account in the interpretation.

Well information for 17 of the 21 wells in this report was obtained from the IHS (table 2). IHS monitors the design and installation of domestic wells on Indian lands. The data available are from information supplied by the drillers who installed the wells for IHS. All of these wells were drilled after 1996 and IHS required a standard construction design for domestic water wells in the area. Depth to water in most of the wells, when the wells were drilled, was about 100 feet below land surface. Most of the wells penetrated from 250 to 400 feet of the aquifer. The data for some of the wells included complete drawdown and recovery data.

Data collected by the U.S. Geological Survey during this investigation (table 2) are pumping well data from four domestic wells collected during the summer of 2006, which was a drought period for Oklahoma (Oklahoma Water Resources Board, 2007). Many landowners who were contacted during this period did not want aquifer tests performed on their well because of lower than normal water levels and poorer productivity of their wells. The landowners reported their wells could be pumped dry in a few hours, if pumped continuously, and the water-level recovery period would be more than 24 hours. Because of these concerns and the small number of domestic wells in the northwest part of the aquifer on the reservation, no aquifer tests were obtained from that area.

Aquifer tests by the U.S. Geological Survey were performed by using a Druck PDCR $35^{\circledR}$ transducer with a measurement range of 0 to 25 pounds per square inch. This range allowed the transducer to be lowered 30 feet below the static water level in a well, which was determined by using a steel tape. The well was then pumped continuously until water-level drawdown stabilized. When the pump was turned off, the water level was allowed to recover to the initial static level. The water-level data were collected by a Campbell Scientific data logger during the drawdown and recovery periods.

The transducer was field checked and calibrated before the first aquifer test. The transducer was lowered into each well with an electric water level tape to check the accuracy of the readings at the static water level and then lowered to the maximum functional depth of the transducer. Field calibration measurements were used to develop a regression between measured water depth and pressure and a correction factor for the pressure data (Freeman and others, 2004).

\section{Aquifer Test Analysis Methods and Results}

Based on drilling information, the 21 wells analyzed for aquifer properties in this report are considered to be completed in the confined part of the aquifer. Drilling depth of the 21 wells in this report ranged from 140 to 400 feet and averaged 234 feet. Depth of the casing ranged from 120 to 380 feet and averaged 214 feet. Static water level in the wells ranged from 54 to 200 feet and averaged 104 feet.

Transmissivity values for the 21 wells in this report are presented in table 2. AQTESOLV ${ }^{\circledR}$ software (HydroSolve, 2006) was used to calculate transmissivity for 10 of the 21 wells where sufficient drawdown or recovery data were available. For the AQTESOLV calculated transmissivities, the aquifer was assumed to have a thickness of 400 feet and a static water level of 100 feet below land surface. IHS drilling information indicates these assumptions are appropriate for the confined part of the aquifer. Accordingly, aquifer-test analysis methods described in Cooper and Jacobs (1946), Papadopulos and Cooper (1967), and Agarwal (1980) were used to analyze the drawdown and recovery data. The test data are on file at the U.S. Geological Survey, Oklahoma Water Science Center in Oklahoma City.

Eleven of the aquifer tests did not have adequate data to reliably calculate a transmissivity value. Transmissivity values for these wells (table 2) were estimated from the specific capacity of the pumping wells using equation 1 (Parkhurst and others, 1996).

$$
T=242 \frac{Q}{S}
$$

where: $\mathrm{T}$ is transmissivity, in feet squared per day;

$\mathrm{Q}$ is discharge, in gallons per minute; and

$\mathrm{s}$ is drawdown, in feet.

The estimated transmissivity values probably have a greater error range than the calculated values but do provide relative aquifer productivity information in the area of the well. The estimated transmissivity values are 1.1 to 4.3 times greater than the calculated transmissivity values in table 2 and have a mean of 1.9 times greater than the calculated values.

Likewise, the estimated transmissivity values in table 1 (D'Lugosz and others, 1986) were calculated using equation 1. These estimated values also are greater than the calculated transmissivity values (table 2).

\section{Characterization of Transmissivity}

The calculated and estimated transmissivity values shown in table 2 in bold font are presented in figures 2, 3, and 4. These transmissivity values range from 5 to 1,000 feet squared per day. 
Table 2. Ada-Vamoosa aquifer test information, including pumping rate, water-level drawdown, specific capacity, estimated and calculated transmissivity, and calculation method used.

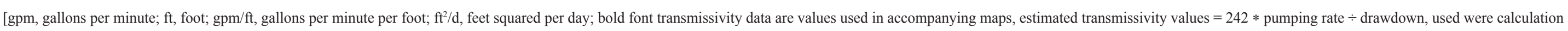
values could not be determined; transmissivity calculations were made using software by HydroSolve, Inc., AQTESOLV ${ }^{\circledR}$ Version 4.01, copyright 1996-2006, Reston, Virginia]

\begin{tabular}{|c|c|c|c|c|c|c|c|c|c|}
\hline Site ID & $\begin{array}{l}\text { Township and } \\
\text { range }\end{array}$ & $\begin{array}{c}\text { Aquifer test } \\
\text { by }\end{array}$ & Date & $\begin{array}{l}\text { Pumping } \\
\text { rate } \\
\text { (gpm) }\end{array}$ & $\begin{array}{l}\text { Drawdown } \\
\text { (ft) }\end{array}$ & $\begin{array}{l}\text { Specific } \\
\text { capacity } \\
\text { (gpm/tt) }\end{array}$ & $\begin{array}{c}\text { Estimated } \\
\text { transmissivity } \\
\left(\mathrm{ft}^{2} / \mathrm{d}\right)\end{array}$ & $\begin{array}{c}\text { Calculated } \\
\text { transmissivity } \\
\left(\mathrm{ft}^{2} / \mathrm{d}\right)\end{array}$ & $\begin{array}{l}\text { Transmissivity } \\
\text { calculation } \\
\text { method }\end{array}$ \\
\hline 364823096105101 & T27N-R10E & U.S. Geological Survey & 09/05/2006 & 3.5 & 12 & 0.29 & 70 & 44 & Papadopulos-Cooper (1967) \\
\hline 362803096223501 & T23N-R09E & Indian Health Service & 11/20/1996 & 12 & 75 & 0.16 & 40 & -- & \\
\hline 362302096253701 & T22N-R08E & U.S. Geological Survey & $08 / 31 / 2006$ & 6.7 & 8.6 & 0.78 & 190 & 44 & Cooper-Jacobs (1946) \\
\hline 364044096170101 & T25N-R09E & Indian Health Service & $04 / 07 / 2000$ & 14 & 31.5 & 0.44 & 110 & 70 & Papadopulos-Cooper (1967) \\
\hline 362404096212201 & T22N-R09E & Indian Health Service & $07 / 24 / 2004$ & 5 & 62 & 0.08 & 20 & -- & \\
\hline 364007096141101 & $\mathrm{~T} 25 \mathrm{~N}-\mathrm{R} 10 \mathrm{E}$ & Indian Health Service & $10 / 30 / 1997$ & 14 & 42 & 0.33 & 80 & -- & \\
\hline 362621096312701 & T23N-R07E & Indian Health Service & $08 / 04 / 2004$ & 10 & 44 & 0.23 & 55 & -- & \\
\hline 362623096320001 & T23N-R07E & Indian Health Service & $05 / 25 / 2005$ & 13.6 & 28.1 & 0.48 & 120 & $100-110$ & Papadopulos-Cooper (1967) \\
\hline 362252096284601 & T22N-R08E & Indian Health Service & 05/08/1998 & 8 & 45 & 0.18 & 45 & -- & \\
\hline 363156096332901 & T26N-R09E & Indian Health Service & $06 / 17 / 2002$ & 2.5 & 55 & 0.05 & 10 & -- & \\
\hline 363803096205501 & T25N-R09E & Indian Health Service & 03/03/1998 & 5 & 165 & 0.03 & 5 & -- & \\
\hline 364857096103001 & $\mathrm{~T} 27 \mathrm{~N}-\mathrm{R} 10 \mathrm{E}$ & Indian Health Service & $09 / 14 / 2005$ & 5 & 36.9 & 0.14 & 35 & 22 & Papadopulos-Cooper (1967) \\
\hline 363255096210602 & T24N-R09E & Indian Health Service & $03 / 16 / 2004$ & 13 & 15 & 0.87 & 210 & -- & \\
\hline 364319096180601 & T26N-R10E & U.S. Geological Survey & $01 / 12 / 2006$ & 7.8 & 9 & 0.87 & 210 & $112-1,000$ & $\begin{array}{l}\text { Papadopulos-Cooper (1967), } \\
\text { Agarwal (1980) }\end{array}$ \\
\hline 362330096222801 & T24N-R07E & Indian Health Service & 08/17/1999 & 5 & 93 & 0.05 & 15 & -- & \\
\hline 362444096342101 & T22N-R07E & Indian Health Service & 02/23/1998 & 10 & 25 & 0.40 & 100 & -- & \\
\hline 363230096222401 & T24N-R09E & U.S. Geological Survey & $08 / 25 / 2006$ & 11 & 12 & 0.92 & 220 & 56 & $\begin{array}{l}\text { Papadopulos-Cooper (1967), } \\
\text { Agarwal (1980) }\end{array}$ \\
\hline 361504096182501 & T21N-R09E & Indian Health Service & $06 / 11 / 2003$ & 15 & 70 & 0.21 & 50 & 38 & Papadopulos-Cooper (1967) \\
\hline 362343096305801 & T22N-R07E & Indian Health Service & $07 / 07 / 2006$ & 10 & 19.4 & 0.51 & 120 & 130 & Papadopulos-Cooper (1967) \\
\hline 363443096191801 & T24N-R09E & Indian Health Service & $06 / 10 / 2004$ & 12 & 107 & 0.11 & 30 & -- & \\
\hline 362516096283701 & T23N-R08E & Indian Health Service & $12 / 06 / 2005$ & 6 & 31 & 0.19 & 50 & 21 & Papadopulos-Cooper (1967) \\
\hline
\end{tabular}




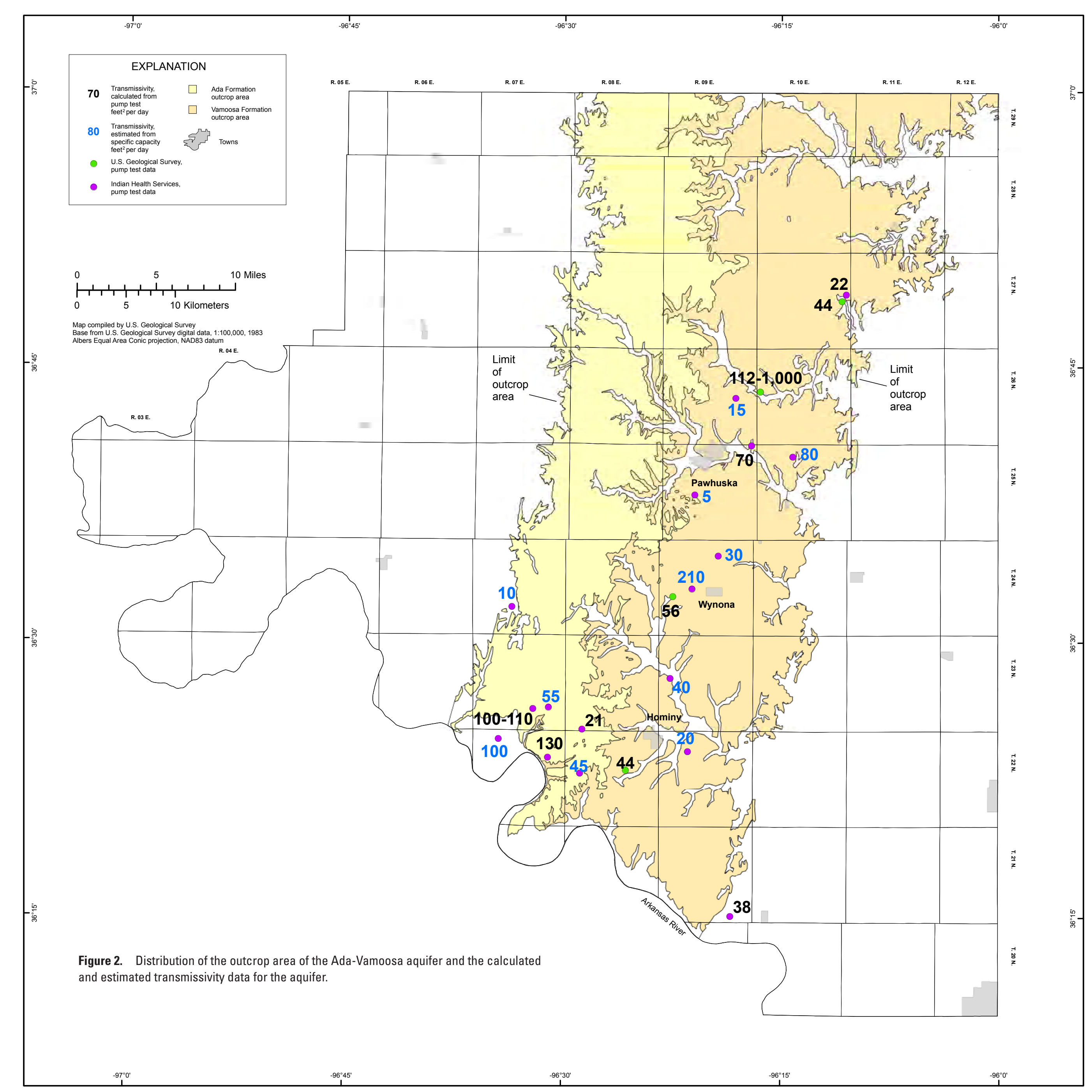




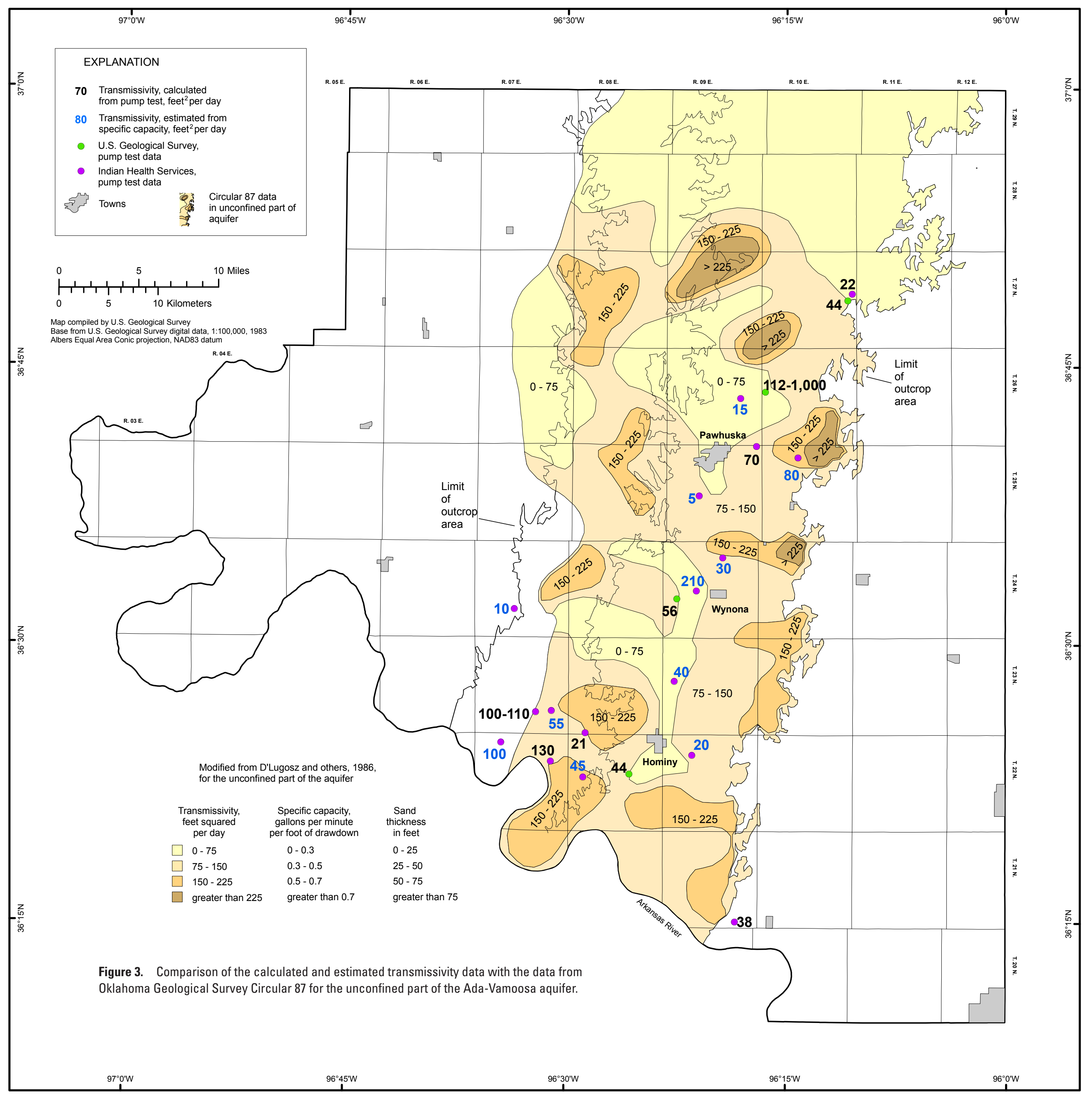




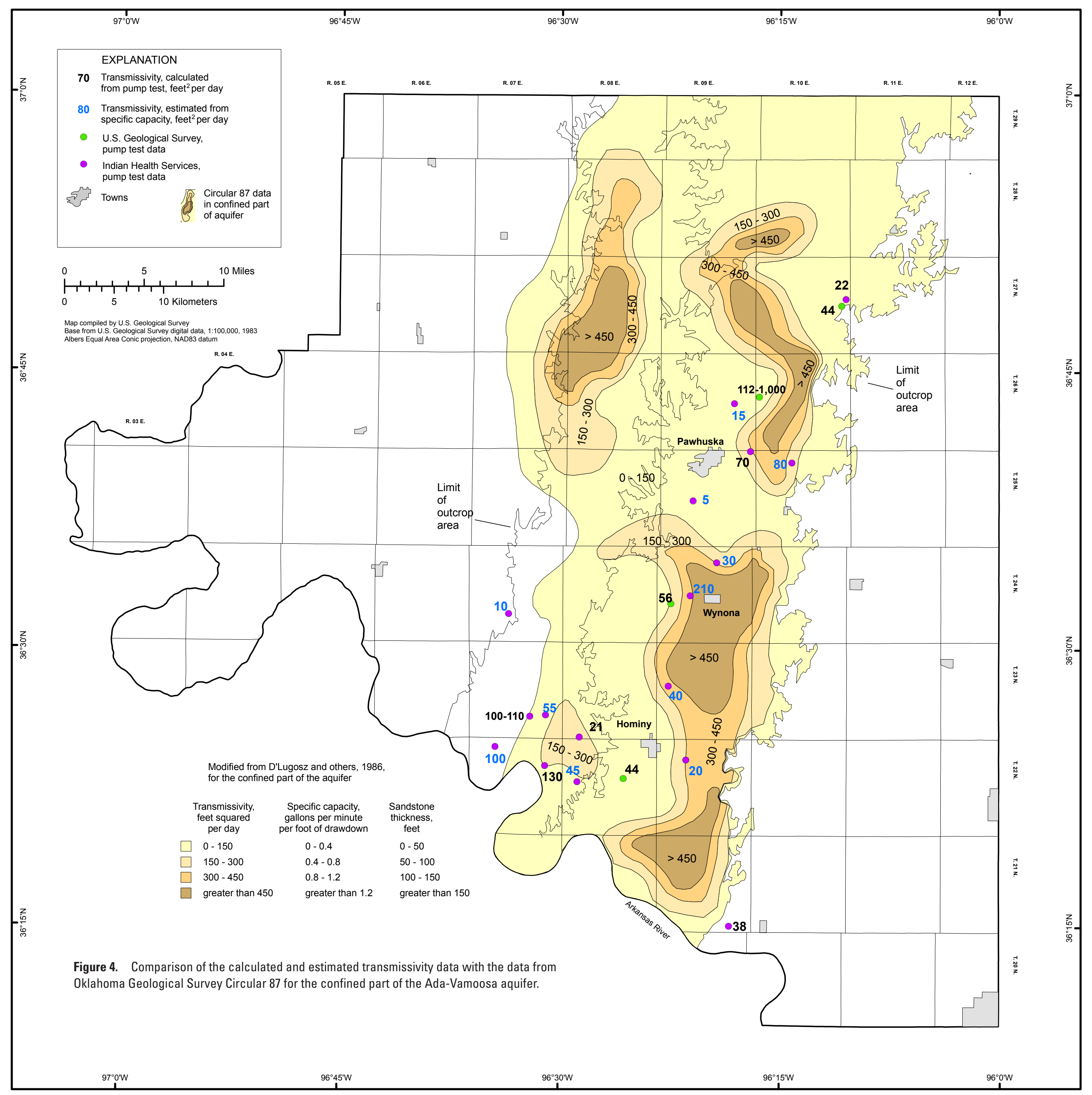


The well located in T21N-R09E (fig. 2) with a transmissivity value of 38 feet squared per day is not in the AdaVamoosa outcrop area (Bingham and Bergman, 1980, plates 1 and 2). However, the aquifer test results illustrate the producing potential of the minor aquifers lower in the Pennsylvanian rock sequence.

The aquifer test data from the well with 1,000 feet squared per day, northeast of Pawhuska, did not fit the assumptions of the analysis method. The variability in the calculation was because of a shift in the drawdown data during the pump test. Such a shift could result from the well receiving an increasing proportion of water from the overlying valley alluvium after initially withdrawing water mostly from the Ada-Vamoosa aquifer. Two transmissivity values are reported for this well. The lesser value uses only the earlier data in the calculation and the greater value uses all the data.

Figures 3 and 4 are modified from Circular 87 (D'Lugosz and others, 1986) and are presented here for discussion only with the data from the current study. The maps were modified from the publication to adhere to the eastern outcrop limit of the base of the aquifer in Bingham and Bergman (1980).

Figure 3 is presented in Circular 87 as the unconfined part of the Ada-Vamoosa aquifer. As previously discussed, the western area of figure 3 along the Ada Formation outcrop (figs. 1 and 2) probably has less potential for water production than shown in Circular 87 because of the limestone and shale sequence. The eastern area on figure 3, along the Vamoosa Formation outcrop (figs. 1 and 2), is the recharge area for the aquifer on the reservation. Areas where the sandstones are cropping out are the unconfined part of the aquifer. These areas are generally east and northeast of Pawhuska and east of Wynona and Hominy.

Figure 4 is shown in Circular 87 as the confined part of the Ada-Vamoosa aquifer. The transmissivity values in the current study are thought to be from the confined part of the aquifer because of data from the IHS drilling information indicating the depths to water and the depths of the wells. Therefore, the transmissivity values from the current study should be more similar to figure 4 than figure 3 . Twelve of the wells from this study were within the range of predicted transmissivity values from Circular 87 (fig. 4). The matching wells on figure 4 are on the area of the aquifer with 0 to 150 feet squared per day. This also is the largest area on the map. Six of these are calculated transmissivity values and six are estimated transmissivity values. The western boundary of the aquifer is defined in Circular 87 as the limit of usable ground water containing 1,500 milligrams per liter or less of dissolved solids. However, two of the wells in the current study, located west of the limit of usable ground-water boundary, were completed as domestic wells, indicating the presence of usable water. The western boundary of usable water in the aquifer probably varies locally on the reservation.

Five areas on figure 4 are indicated with transmissivity values greater than 450 feet squared per day. The northwestern area is farther from the recharge area of the aquifer and is confined below the Ada Formation (fig. 2). In 2006, few wells existed in this area. Over pumping of existing wells or significant additional well development in this area of the aquifer could pull the naturally occurring saline water, which is expected to be down dip to the west (D'Lugosz and others, 1986), up into the fresh water stored in the aquifer. The four areas with greater transmissivity values along the eastern half of the aquifer (fig. 4) are on the Vamoosa Formation outcrop area (fig. 2) and the recharge area of the aquifer (fig. 3). The well west of Wynona with an estimated transmissivity of 210 feet squared per day indicates these areas may have potential for ground-water development. There are wells from the current study along the edges of these four areas with transmissivity values less than predicted in Circular 87 . These data may indicate the areas are not as large or uniformly continuous as presented in Circular 87.

\section{References}

Abbott, Marvin, 2000, Water quality of the Quaternary and Ada-Vamoosa Aquifers on the Osage Reservation, Osage County, Oklahoma, 1997: U.S. Geological Survey WaterResources Investigations Report 99-4231. 76 p. (Available at http://pubs.usgs.gov/wri/wri994231/pdf/wri99-4231.pd])

Alley, William, 1994, Guidance for the preparation, approval, and archiving of aquifer test results, Office of Ground Water technical memo 94.02. (Available at http://water.usgs.govd admin/memo/GW/gw94.02.htm )

Agarwal, R.G., 1980, A new method to account for producing time effects when drawdown type curves are used to analyze pressure buildup and other test data: Society for Petroleum Engineers, Society of Petroleum Engineers 55th Annual Fall Technical Conference, September 2 1-24, Dallas, Texas: SPE Paper 9289).

Bingham, R.H., and Bergman, D.L., 1980, Reconnaissance of the water resources of the Enid quadrangle, north-central Oklahoma: Oklahoma Geological Survey Hydrologic Atlas 7, 4 sheets, scale 1:250,000.

Cooper, H.H. and Jacobs, C.E., 1946, A generalized graphical method for evaluating formation constants and summarizing well field history: American Geophysical Union Transactions, v. 27, p. 526-534.

D’Lugosz, J.J., McClafin, R.G., and Marcher, M.V., 1986, Geohydrology of the Vamoosa-Ada aquifer, east-central Oklahoma: Oklahoma Geological Survey Circular 87, 41 p.

Driscoll, F.G., 1986, Groundwater and wells (2nd ed.): St. Paul, Minn., Johnson Filtration Systems, Inc., 1,089 p.

Fetter, C.W., 1994, Applied hydrogeology (3rd ed.): Engelwood Cliffs, N.J., Prentice Hall, 691 p. 
Greig, P.B., 1959, Geology of Pawnee County, Oklahoma: Oklahoma Geological Survey Bulletin 83, 188 p.

Freeman, L.A., Carpenter, M.C., Rosenberry, D.O., Rousseau, J.P., Unger, Randy, and McLean. J.S., 2004, Use of submersible pressure transducers in water-resources investigations: U.S. Geological Survey Techniques of WaterResources Investigations, book 8, chap. A3, 52 p. (Available at http://pubs.usgs.gov/twri/twri8a3,)

Heath, R.C., 1983, Basic ground-water hydrology: U.S. Geological Survey Water-Supply Paper 2220, 84 p. (Available at http://pubs.er.usgs.gov/usgspubs/wsp/wsp2220)

HydroSolve, Inc., 2006, AQTESOLV Version 4.01, copyright 1996-2006, Reston, Virginia.

Lohman, S.W., Bennett, R.R., Brown, R.H., Cooper, H.H., Jr., Drescher, W.J., Ferris, J.G., Johnson, A.I., McGuinness, C.L., Piper, A.M., Rorabaugh, M.I., Stallman, R.W., and Theis, C.V., 1972, Definitions of selected ground-water terms-Revisions and conceptual refinements: U.S. Geological Survey Water-Supply Paper 1988, 21 p.

McClymonds, N.E., and Franke, O.L., 1972, Water-transmitting properties of aquifers on Long Island, New York: U.S. Geological Survey Professional Paper 627-E, 24 p.
Oakes, M.C., 1959, Geology of Creek County: Oklahoma Geological Survey Bulletin 81, 134 p.

Oklahoma Water Resources Board, 2007, in Hydrologic drought of water year 2006- A historical context: Oklahoma Water Resources Board, 4 p.

Papadopulos, I.S. and Cooper, H.H., 1967, Drawdown in a well of large diameter: Water Resources Research, v. 3, no. 1, p. 241-244.

Parkhurst, D.L., Christenson, Scott, and Breit, G.N., 1996, Ground-water-quality assessment of the Central Oklahoma aquifer, Oklahoma: Geochemical and geohydrologic investigations: U.S. Geological Survey Water-Supply Paper 2357-C, 101 p.

Shelton, J.W., Ross, J.S. Garden, A.J., Franks, J.L., 1985, Geology and mineral resources of Payne County, Oklahoma: Oklahoma Geological Survey Bulletin 137, 92 p.

U.S. Environmental Protection Agency, Drinking Water Contaminants, accessed May 19, 2008, at http://www.epa.gov/ safewater/contaminants/index.htm 